\title{
Barbarians at the British Museum: Anglo-Saxon art, race and religion
}

\author{
Katherine Cross
}

Pre-publication version of chapter (February 2019), published with images in Empires of Faith in Late Antiquity: Histories of Art and Religion from India to Ireland, ed. by Jaś Elsner (Cambridge: CUP, 2020), pp. 396-433. Available as ebook at

https://doi.org/10.1017/9781108564465.

\section{Early Medieval Identities in the Museum}

In his March 2014 review of the British Museum's revamped Early Medieval gallery, art critic Waldemar Januszczak extolled the workmanship of the art displayed there as an indication that the barbarian peoples were not that uncultured after all:

One by one, the other barbarian tribes step up to join the bling fest. The Franks decorated the weapons they used to bang other barbarians on the head with gorgeous silver inlay. The Vandals preferred beefy jewellery made of gold and onyx. The Vikings demanded silver brooches that grew bigger and bigger. The Visigoths were almost as skilled as the AngloSaxons in the working of gold and garnets... The exquisite religious wares of the Byzantines give this important cultural rewrite the superb ending it deserves. ${ }^{1}$

Januszczak saw the artefacts in the new gallery as the autochthonous expression of various ethnic groups - 'tribes' - who were naturally differentiated in their artistic styles as in other aspects of their identities. Notably, he attributes religious meaning only to the Byzantine heirs of the Roman Empire; the barbarian arts are typified as the gaudy, ostentatious display of weapons and wealth.

This presentation, though Januszczak saw it as a 'rewrite', reflects a long-held model of Late Antiquity in the West, characterized by a firm distinction between the Romans of the failing Empire, and the barbarian peoples who invaded and established new kingdoms. These peoples - Franks, Vandals, Visigoths, Angles, Saxons, elsewhere Goths and Lombards, and here Vikings as their later counterparts - were identified in the historical record and envisaged as different, internally homogeneous and externally bounded ethnic groups. As Patrick Geary has elucidated, this narrative, reinforced by the association of historically recorded groups with languages and archaeological cultures, proved powerful in underpinning nineteenth-century nationalist aims. ${ }^{2}$ According to the model, as the barbarian peoples established kingdoms in the wreckage of the empire, these kingdoms took on their names and cultures (Francia, England, Lombardy), thereby providing an ancient ethnic past and primordial moment of origin for distinct modern nation-states.

Early medieval material culture became tied to this model early in the development of its study. With a few notable exceptions (such as the tomb of Childeric I, excavated in 1653), ${ }^{3}$ it was only in the late eighteenth and nineteenth centuries that a significant number of early

\footnotetext{
${ }^{1}$ W. Januszczak, 'Out of the Darkness Came forth Light: Two Illuminating Shows Take a Fresh Look at German Prints and the Dark Ages', The Sunday Times (30 March 2014) 12-13.

${ }^{2}$ P. Geary, The Myth of Nations: The Medieval Origins of Europe (Princeton 2002), esp. pp. 15-40. See also W. Pohl, 'Modern Uses of Early Medieval Ethnic Origins', in N. Karthaus and K. Lichtenberger (eds) Gebrauch und Missbrauch des Mittelalters, 19.-21. Jahrhundert (Munich 2009) 55-70.

${ }^{3}$ J.-J. Chifflet, Anastasis Childerici I Francorum regis, sive Thesaurus sepulchralis Tornaci Neruiorum effossus, \& commentario illustratus (Antwerp 1655).
} 
medieval artefacts were unearthed and correctly identified as dating from this period. In Britain, the first excavations of Anglo-Saxon cemeteries took place in the second half of the eighteenth century, most notably - and prolifically - by the Reverend Bryan Faussett (in Kentish excavations of 1759-73; d. 1776), although he believed them to be the remains of 'Britons Romanized' or 'Romans Britonized'; subsequently, James Douglas used datable coins and comparison of burial assemblages to propose correctly that these were all graves from the early Anglo-Saxon period, but such interpretations were not widely accepted before the publications of Charles Roach Smith and John Yonge Akerman in the 1840s. ${ }^{4}$ Throughout the nineteenth century, collectors grew to consider such excavations as sources of valuable artefacts. The expansion of railway networks across France and England resulted in the rapid excavation of hundreds of Merovingian and Anglo-Saxon cemeteries, and the subsequent formation of personal collections. ${ }^{5}$ In some instances, antiquarian interest in the material evidence of the Early Middle Ages was closely linked to a broader medievalism: thus, restoration of medieval churches in the late Victorian era led to the recovery of a considerable amount of Anglo-Saxon and Anglo-Scandinavian stone sculpture. ${ }^{6}$ The prevailing nineteenthcentury historical framework of barbarian invasion and Völkerwanderung encouraged the attribution of ethnic labels to these archaeological discoveries. At first primarily illustrative of this narrative, the work of antiquarians and archaeologists soon began to highlight material culture's potential for revealing historical cultures and the movements of peoples.

Very early in the field's genesis, identitarian concerns began to motivate the collection and discussion of early medieval material culture. ${ }^{7}$ Much of the foundational work was carried out

\footnotetext{
${ }^{4}$ B. Faussett, Inventorium Sepulchrale: An Account of Some Antiquities dug up at Gilton, Kingston, Sibertswold, Barfriston, Beakesbourne, Chartham, and Crundale, in the County of Kent, from A.D. 1757 to A.D. 1773, ed. C.R. Smith (London 1856), pp. 38-39 (with comment from Smith, n. 1); J. Douglas, Nenia Britannica, or A Sepulchral History of Great Britain from the Earliest Period to Its General Conversion to Christianity (London 1793), pp. v-vi, 122-31; S.C. Hawkes, 'Bryan Faussett and the Faussett Collection: An Assessment', in E. Southworth (ed.) Anglo-Saxon Cemeteries: A Reappraisal (Stroud 1990) 1-24, at p. 4; M. Rhodes, 'Faussett Rediscovered: Charles Roach Smith, Joseph Mayer, and the Publication of Inventorium Sepulchrale', in E. Southworth (ed.) Anglo-Saxon Cemeteries: A Reappraisal (Stroud 1990) 25-64, at pp. 48-49; S. Lucy, S. The Anglo-Saxon Way of Death: Burial Rites in Early England (Stroud 2000), pp. 8-11.

${ }^{5}$ B. Effros, Uncovering the Germanic Past: Merovingian Archaeology in France, 1830-1914 (Oxford 2012); Lucy 2000, p. 8.

${ }^{6} \mathrm{M}$. Townend, The Vikings and Victorian Lakeland: The Norse Medievalism of W.G. Collingwood and His Contemporaries (Kendal 2009), p. 133.

${ }^{7}$ Although the following discussion concentrates primarily on identity within the British Isles, much is relevant also to American scholarship: Anglo-Saxon history and culture has played a powerful role in the formation of the identity of the USA and its tradition of literary studies. Let it merely be noted here that Thomas Jefferson established the first department of Anglo-Saxon studies at the University of Virginia in 1825, and planned to place Hengest and Horsa on the Great Seal of the USA. See A. Frantzen, The Desire for Origins: New Language, Old English, and Teaching the Tradition (London 1990), pp. 15-16; C. Hills, Origins of the English (London 2003), p. 34. Since I wrote this chapter in 2015, US medievalists have led the way in highlighting the modern racist connotations of the term 'Anglo-Saxon' and the ongoing use of the period in the service of white supremacy, within and without the academy. See S. Lomuto, 'White Nationalism and the Ethics of Medieval Studies', In the Middle (5 December 2016), http://www.inthemedievalmiddle.com/2016/12/white-nationalism-and-ethics-of.html; M. Dockray-Miller, ‘Old English Has a Serious Image Problem', JStor Daily (3 May 2017), https://daily.jstor.org/old-english-serious-image-problem/; A. Miyashiro, 'Decolonizing Anglo-Saxon Studies: A Response to ISAS in Honolulu', In the Middle (29 July 2017), http://www.inthemedievalmiddle.com/2017/07/decolonizing-anglo-saxon-studies.html; D. Wilton, 'What Do We Mean by Anglo-Saxon? Pre-Conquest to the Present', JEGP (forthcoming 2020), http://wordorigins.org/documents/Wilton_JEGP_AS_Paper_Pre-Publication_Draft.pdf [all accessed 11 October 2019].
} 
by members of local learned societies with antiquarian and archaeological interests. Bonnie Effros's discussion of the origins of Merovingian archaeology highlights that study of this material first served regional identities; collectors interested in the past of their own provinces felt threatened by the encroachment of national museums. ${ }^{8}$ In England, on the other hand, the Trustees of the British Museum were reluctant to acquire early medieval material from the British Isles, and suggested regional museums were in fact the best place for these artefacts.' But gradually, in the mid-nineteenth century, museums in north-west Europe began to create collections of 'national antiquities'. Since historians identified the migrations of barbarian peoples and establishment of new kingdoms as moments of origin for modern nations, artefacts associated with these movements acquired special significance. In England, members of national and local antiquarian societies emphasised the status of the Anglo-Saxon era as a period of national origin, which then imbued its art with the ability to reveal natural, innate and typical characteristics of the English people. On this basis, they encouraged the British Museum to acquire early medieval artefacts from the British Isles. ${ }^{10}$

The formation of national collections was a matter of nineteenth-century national competition. Curators' correspondence shows attempts to imitate and surpass one another. Copenhagen was proposed as a model for the British Museum and the Musée des antiquités nationales in Saint-Germain-en-Laye (inaugurated 12 May 1867); in 1861, the curator of the Römich-Germanisches Zentralmuseum in Mainz, Ludwig Lindenschmit, judged that the new French collection would immediately surpass that of the British Museum, where the collection of early medieval artefacts had been resisted. ${ }^{11}$ Edward Hawkins, Keeper of Antiquities at the British Museum from 1826 until 1860, was primarily responsible for persuading the Trustees that 'national antiquities' had a place, drawing comparisons with Copenhagen and Edinburgh. ${ }^{12}$ As a result of the Royal Commission's report on the subject in 1850, Augustus Wollaston Franks was appointed to be responsible for national antiquities. Franks acquired the fundaments of the Museum's early medieval holdings, although the Trustees were not easily convinced to devote the funds to this marginalised aspect of the Museum's collections. ${ }^{13}$ In 1853, they refused to buy the Faussett collection of artefacts from

\footnotetext{
${ }^{8}$ Effros 2012, p. 27.

${ }^{9}$ C.R. Smith, 'The National Antiquities', in id. Collectanea Antiqua: Sketchings and Notices of Ancient Remains Illustrative of the Habits, Customs and History of Past Ages, vol.3 (London 1857) 266-269, at pp. 268-69. Once there were sympathetic curators, however, the British Museum was able to trump the claims of local museums on occasion, for instance in the case of the Æthelswith ring: D.M. Wilson, The Forgotten Collector: Augustus Wollaston Franks of the British Museum (London 1984), p. 30. Regional identities are again playing a significant role in the UK: see, for a recent example, M. Capper and M. Scully, 'Ancient Objects with Modern Meanings: museums, volunteers, and the Anglo-Saxon 'Staffordshire Hoard" as a marker of twenty-first century regional identity', Ethnic and Racial Studies 39.2 (2016) 181-203.

${ }^{10}$ On the disjuncture between antiquarian discoveries and museum collections, see R. McCombe,

'Anglo-Saxon Artifacts and Nationalist Discourse', Museum History Journal 4.2 (2011), 139-160.

${ }^{11}$ Effros 2012, pp. 267-73.

12 D.M. Wilson, The British Museum: A History (London 2002), pp. 89-90, 386. Likewise A.W. Franks, 'On the Additions to the Collection of National Antiquities in the British Museum', Antiquaries Journal 10 (1853) 1-13, at p. 13: 'It is sad, however, to compare our own scanty beginnings with the magnificent series of National Antiquities which the Danish antiquaries have formed'.

${ }^{13}$ M. Caygill, "'Some recollection of me when I am gone": Franks and the Early Medieval Archaeology of Britain and Ireland', in ead. and J. Cherry (eds) A.W. Franks: Nineteenth-Century Collecting and the British Museum (London 1997) 160-183, traces the progress of Franks's acquisitions of early medieval artefacts for the Museum.
} 
Anglo-Saxon cemeteries in Kent, which was championed by the antiquary and archaeologist Charles Roach Smith. Smith forcefully expressed his anger at their refusal, arguing that

The public voice had long been raised against the unaccountable absence of National Antiquities in the National Museum. Foreigners had long reproached us for the neglect with which we treated the valuable remains of ancient art illustrative of our own history... Their patriotism and common sense were shocked at this repudiation; and they asked if the people of England were so destitute of memorials of the races from whom they descended, that even their chief Museum could not afford examples? ${ }^{14}$

Three aspects of Smith's invective are particularly revealing. Firstly, he used the language of race to express his belief that early medieval artefacts revealed an essential part of the national story (in an addendum on the subject of their refusal, he consequently rechristened it 'the Anti-British Museum'). ${ }^{15}$ Following from this, Smith viewed the museum's stance as a matter of international competition, invoking foreign visitors to give voice to his dismay. ${ }^{16}$ His other weapon was 'the public voice', always a matter of particular concern for the publically funded museum, and one which continues to affect interpretations within such institutions.

When Roach Smith offered his own collection to the Museum in 1855, Franks argued for its purchase by utilising similar arguments relating to national pride, as he wrote to Hawkins:

The collection would be a great and valuable addition to the British Room and the acquisition of it by the Museum would go far to remove from us the reproach under which we are labouring of neglecting the antiquities of our own Country, while we accumulate those of other lands. I have had many proofs that such a feeling exists and that it has prevented in several cases donations being made to us. ${ }^{17}$

Perhaps the outcry over their refusal of the Faussett collection (and associated loss of William Wylie's collection from Fairford) ${ }^{18}$ had encouraged the Trustees, for they bought Roach Smith's own collection for a reduced price in 1856. But Franks had to wait until 1866 for his own department of British and Medieval Antiquities and Ethnography. The early medieval acquisitions made by Franks over the succeeding years, including the Trewhiddle Hoard

\footnotetext{
${ }^{14}$ C.R. Smith, 'The Faussett Collection of National Antiquities' [repr. from id. Collectanea Antiqua, vol.3], Archaeological Tracts (London 1854), p. 7. See A. MacGregor, 'Antiquity Inventoried: Museums and "National Antiquities" in the Mid-Nineteenth Century', in V. Brand (ed.) The Study of the Past in the Victorian Age (Oxford 1998) 125-137.

${ }^{15}$ Smith 1857, p. 269.

${ }^{16}$ Effros 2012, pp. 23-24, quotes the Danish archaeologist Jens Jacob Asmussen Worsaae's advice to the English, which reveals a similar belief in the importance of early medieval archaeology for an understanding of modern nations and international relations: 'A nation ... must of necessity direct its attention to bygone times, with the view of enquiring to what stock it belongs, in what relations it stands to other nations, whether it has inhabited the country from primeval times or immigrated thither at a later period, to what fate it has been exposed; so as to ascertain by what means it arrived at its present character and condition' (The Primeval Antiquities of Denmark, translated and applied to the illustration of similar remains in England by W.J. Thoms (London 1849).)

${ }^{17}$ A.W. Franks (British Museum Officers' Reports, liv (Jan.-May 1855), 10/2/55), quoted in Wilson 1984b, p. 24.

${ }^{18}$ Wylie had promised the collection to the Museum, should the Trustees acquire the Faussett collection. Since this did not transpire, the Fairford collection was donated to the Ashmolean Museum in Oxford. On Wylie and the relationship of his excavations to contemporary intellectual and identitarian trends, see H. Williams, 'Anglo-Saxonism and Victorian Archaeology: William Wylie's Fairford Graves', Early Medieval Europe 16 (2008) 49-88.
} 
containing a very early chalice, and the Franks Casket which now bears his name, reveal the expansion of the collections to include Christian art from Anglo-Saxon and Celtic Britain, rather than only items from the very early period excavated from furnished burials. ${ }^{19}$ Celtic objects were collected as part of the heritage of the British Isles, although here the status of the British Museum in relation to the more explicitly national museums in Edinburgh and Dublin was unclear. ${ }^{20}$ Any early medieval artefacts from outside the British Isles - such as the Bähr collection of Baltic grave-goods acquired by Hawkins in 1851-52 - were explicitly described as comparators to the 'native' collections. ${ }^{21}$

Identitarian concerns arising from nineteenth-century nationalism thus shaped the collection, classification and study of early medieval artefacts at a formative moment. Such interest rested on the ascription of ethnic/national labels to these artefacts and their interpretation within contemporary notions of race. Indeed, ancestral identifications, reinforced by culturehistorical classifications, persist and still often constitute Anglo-Saxon art's main attraction. Early Anglo-Saxon art attracted visitors to the British Museum's 1991 exhibition under the title The Making of England, and the exhibition catalogue opened with the words: 'The Anglo-Saxons, whose artistic, technological and cultural achievements in the seventh, eighth and ninth centuries are displayed in this exhibition, were the true ancestors of the English of today'. ${ }^{22}$ Furthermore, despite the partial rejection of these racial ideologies and increasing complexity of ethnic identity within scholarly discourse, a similar ancestralist perspective dominates consideration of early medieval art in academic writing. The author of one of the most theoretically sophisticated recent overviews recognized this tendency in her own approach, reflecting that 'those of us who study "national" arts or literatures generally both desire and help to perpetuate these fantasies' of wholeness, continuity and national identity. ${ }^{23}$ Indeed, Catherine Karkov's explicit aim in this book is to discuss 'the processes of becoming a culture or a nation', which she again locates in the Anglo-Saxon period - 'the centuries in

\footnotetext{
${ }^{19}$ Wilson 2002, p. 165. The Trustees refused to buy the Franks Casket in 1858, and so Franks bought it himself, and donated it to the Museum in 1867: Caygill, 'Some recollections of me when I am gone', pp. 160-62. It is now a celebrated 'highlight' object in the Museum's early medieval gallery.

${ }^{20}$ On the rare occasion the British Museum's acquisition of Celtic objects caused controversy, the potential for competition between the museums was investigated by a parliamentary committee: Celtic Ornaments found in Ireland. Return to an order of the Honourable the House of Commons dated 1 May 1899 (London 1899). In these investigations, British Museum representatives argued that their collections should fully reflect the heritage of the entire British Empire; Irish and Scottish antiquaries and curators, however, suggested that the British Museum should concentrate on England, and referred to their own roles among contemporary European museums. George Coffrey stated (pp. 36, 633) 'In fact, the idea of a national museum has not been developed at the British Museum in the sense in which the term is applied to the national collections in the museums at, say, Copenhagen, Stockholm, Berlin, and Paris (St. Germain). The museums at Dublin and Edinburgh, on the contrary, have been developed on the lines of the museums mentioned, and fulfil the purpose of national museums for Scotland and Ireland in a higher degree than the British Museum does for England.'

${ }^{21}$ Wilson 2002, p. 132; British Museum: Guide to the Exhibition Rooms of the Departments of Natural History and Antiquities (London 1859), p. 100.

${ }^{22}$ L. Webster and J. Backhouse (eds), The Making of England: Anglo-Saxon Art and Culture, AD 600900 (London 1991), p. 9. Such presentations have a long history at the Museum: O. M. Dalton, as Keeper of the Department of British and Medieval Antiquities, introduced his deputy R. A. Smith's The British Museum: Guide to Anglo-Saxon Antiquities (London 1923) with the sentiment that, while earlier British collections 'all comprise objects produced by different races inhabiting these islands', the Anglo-Saxon guide 'will make a special appeal to the English people as illustrating what is largely the handiwork of their own forefathers' (p. iii).

${ }^{23}$ C.E. Karkov, The Art of Anglo-Saxon England (Woodbridge 2011), p. 247.
} 
which England was itself coming into being ${ }^{24}$ Unlike in the field of literature, in art historical scholarship of this period such a tendency (and desire) to employ the early medieval period as a birthplace and supplier of our own identities is yet to be explored and interrogated. ${ }^{25}$

Like all assertions of national and ethnic identity, the presentation of Anglo-Saxon art has reflected and promoted the ideological supports of contemporary political relations. Gerald Baldwin Brown believed that his pioneering encyclopaedic work, a multi-volume survey of The Arts in Early England (1903-1937), negated the insulting view of those who 'deprecate the national ability in art' and thus 'have credited the foreigner at one time or another with all the good artistic work of Anglo-Saxon England'. ${ }^{26}$ Such presentations of the Anglo-Saxon period asserted the creative generation of the English against foreign influence. Accordingly, relationships between European countries - especially England and Germany - have coloured interpretations during the nineteenth and twentieth centuries.

For the English, ethnic identification with the early medieval past offered a source of origins in the Anglo-Saxon migrations of the fifth century - but this seemed to assert membership of a Germanic people-group. The philologist and antiquary J. M. Kemble noted the similarities in the material cultures of German burials and cremation urns from England and northern Germany, and his philological expertise led him to apply familiar concepts to the evidence of material forms. Notably, it was the opportunity provided by a visit to a museum displaying this material, and his acquaintance with his colleagues in Hanover, that prompted Kemble's observation of similarity. He used this observation to make an ethnic claim: "the urns of the "Old Saxon" and those of the "Anglo-Saxon", are in truth identical... Keltic they are not... Slavonic they are not... The bones are those of men whose tongue we speak, whose blood flows in our veins' ${ }^{27}$ Kemble's ideas certainly influenced Franks, who edited his Horae Ferales, and began to collect continental artefacts as comparators to the British Museum's Anglo-Saxon collections. ${ }^{28}$ In times of conflict with Germany, however, such 'Germanist' interpretations were less popular. Yet the ethnic paradigm was not dispensed with. Instead, the early medieval evidence was reassessed in order to produce more pleasing interpretations. An early and idiosyncratic manifestation of anti-German sentiment proposed that the AngloSaxons were not Germanic, but Scandinavian. George Stephens, an English philologist and antiquary, and professor at Copenhagen University from 1855, explicitly sought to demonstrate through his monumental work on rune-stones

[t]hat, as the Northmen (the Scandinavians and the English) more nearly, and the ScandoGoths (the Northmen, the Saxons and the Germans) more generally, are all of one blood and tung, so they should all hold together, love and help and defend each other, avoid every

\footnotetext{
${ }^{24}$ Karkov 2011, pp. 1-2.

${ }^{25}$ Cf. Frantzen 1990, and recent work around the term 'Anglo-Saxon', still predominantly in literary studies, as mentioned in note 7 above.

${ }^{26}$ G.B. Brown, The Arts in Early England, 6 vols in 7 (London 1903-1937), vol.3: Saxon Art and Industry in the Pagan Period (1915), p. 5.

${ }^{27}$ J.M. Kemble, 'On Mortuary Urns Found at Stade-on-the-Elbe and Other Parts of North Germany, Now in the Museum of the Historical Society of Hanover', Archaeologia 36 (1856) 270-283, repr. in id. Horae Ferales, or Studies in the Archaeology of the Northern Nations (London 1863) 221-232, at pp. 229-30; it is a sign of the English Kemble's pro-Germanism that his editors, R. G. Latham and A. W. Franks, in publishing Horae Ferales after his death, first had to translate the majority of the text from German into English, since it incorporated lectures for a Hanover audience (p. vi). See also Lucy 2000, p. 11.

${ }^{28}$ Caygill, 'Some recollections of me when I am gone', p. 169.
} 
beggarly temptation to hate or plunder or ruin or "annect" each other, nobly taking their stand as brothers and fulfilling their mission as one great folkship with its own local limits and national duties, in necessary providential counterpoise - but in all friendly harmony with - the great Romance and Magyar and Greek and Slavic and other race-groups. ${ }^{29}$

In short, he explicitly intended his combination of philological and archaeological work to inform contemporary international relations, through the light it cast on ethnic/national identities. Stephens's intense anti-Germanism, which seems to have motivated his historical interpretations, stemmed at least in part from the Prussian annexation of Schlesvig-Holstein in 1864 - which he claimed was supported by 'archaeological fictions' ${ }^{30} \mathrm{He}$ sought to demonstrate that the English originated in the 'Old North', rather than Germany, professing that they should be called 'Scando-Anglic' rather than 'Anglo-Saxon'. Stephens's identification with Scandinavian heritage was competitive: seeing Germans appropriating Norse mythology as their ancestral inheritance, Stephens railed against this as 'theft bodily' from the peoples of the Old North, apparently viewing this as an annexation of cultural heritage equivalent to the territorial annexation he had witnessed. ${ }^{31}$

Stephens's ideas were not widely accepted, however; their impact on material culture studies was limited, as they did not seem adequately to explain the evidence. ${ }^{32}$ In the British Isles themselves, as in France, the divide between Germanic and Celtic ethnicity proved a more popular battleground: who were the true ancestors of the modern inhabitants: the invading barbarians or the indigenous population? The idea of migrating peoples as Germanic (an originally philological designation), although equated at various levels with the influence of modern Germany, was widely accepted and proved too convincing for Stephens to shake. Instead, interpretations of the significance and extent of Germanic conquest in the fifth century fluctuated with modern international relations and cultural ties, the Celtic presence standing for a 'native' element. In England after the First World War, and increasingly after the Second, art historians and archaeologists began to downplay the northern, 'Germanic' influence on Anglo-Saxon art in favour of the 'Celtic', and thereby to argue against a wholesale replacement of the Romano-British by invading Anglo-Saxons. ${ }^{33}$ Similarly in France, after the Franco-Prussian War of 1870 and then again in the postwar period of the 1950s, evidence from Merovingian cemeteries was used to demonstrate that the Frankish migration had been characterised by intermarriage and acculturation with the Gallo-Roman population, rather than conquest. ${ }^{34}$ While the French interpretations related also to class, in

\footnotetext{
${ }^{29}$ G. Stephens, The Old-Northern Runic Monuments of Scandinavia and England, vol.1 (London 1866), pp. xvi-xvii.

${ }^{30}$ Stephens 1866, vol.1, p. x.

${ }^{31}$ A. Wawn, 'George Stephens, Cheapinghaven, and Old Northern Antiquity', Studies in Medievalism 7 (1995) 63-104, at pp. 86-89. For example, the 'Vaterländischer Saal' of the Neues Museum in Berlin was painted in 1852 with a full cycle from the Eddas, depicting Norse gods and mythology, as the appropriate context in which to view the prehistoric artefacts of national German archaeology: see M. Bertram, 'Vaterländischer Saal (Room of National Antiquities)', in E. Blauert with A. Bähr (eds) Neues Museum: Architecture, Collections, History (Berlin 2012) 106-113.

${ }^{32}$ See, for example, Stephens's influence and the eventual rejection of his arguments regarding the origins of the Gosforth Cross (Cumbria): Townend 2009, pp. 125-36.

${ }^{33}$ E.T. Leeds, Early Anglo-Saxon Art and Architecture: Being the Rhind Lectures, Delivered in Edinburgh, 1935 (Oxford 1936), pp. 1-12, 114; Hills 2003, p. 37. Historians, too, responded to the contemporary political moment: W. Levison, England and the Continent in the Eighth Century (Oxford 1946) - the Ford Lectures of 1943.

${ }^{34}$ I. Wood, 'Barbarians, Historians, and the Construction of National Identities', Journal of Late Antiquity 1 (2008) 61-81, at pp. 70-72, 78-79; E. Emery, E. and L. Morowitz, Consuming the Past: The
} 
Britain the two distinct barbarian ethnicities stood for the relative contribution of internal and external forces to modern national identities.

Yet relationships between the home nations also shaped discussion of interaction between Celtic and Anglo-Saxon art and artefacts. ${ }^{35}$ From the second half of the twentieth century, Anglo-Saxon distinctiveness has been defined primarily against the art of the 'Celtic' peoples who, in contrast, have usually been grouped together, and mapped on to the non-English nations of the British Isles. The most prominent debate relates not to museum artefacts, but manuscripts. The Irish or Northumbrian origins of richly illuminated Gospel books such as the Book of Durrow and the Book of Kells, and more particularly the origins of their decorative style, which appears also on items of luxury metalwork, became a point of controversy because of the implications for modern national pride. ${ }^{36}$ The prejudices are clear in E. A. Lowe's influential palaeographic assessment of manuscripts from the British Isles (1935): since their scripts were virtually indistinguishable, he based his attributions on his belief that the Irish were more inclined to 'whim and fancy', while the English were 'balanced and disciplined'. Following this method based on 'temperamental differences', the Book of Durrow was identified as an English work - as in fact, were all accomplished and high-quality manuscripts. ${ }^{37}$ On the other hand, the desire to present a distinct 'Celtic' culture and achievement from an early period encouraged the attribution of the style to the Irish - and ensured its longevity. In 1977, Carl Nordenfalk, although he emphasised the Northumbrian creation of many of these manuscripts, combated arguments against Irish origins for the style itself by claiming that we should not 'deprive Ireland of the honor of having played an essential part in the creation of what has been considered its greatest national exploit' ${ }^{38}$ From an English perspective, the decorative, geometric style of the Gospel books, with its talismanic, magic associations, fed into orientalising images of 'the Visionary Celt' - a Romantic idea of the Irish, Scottish and Welsh, which was shaped by medieval literature as well as the contemporary politics of Irish revivalism. ${ }^{39}$ In Celtic regions, scholars and public alike enthusiastically adopted these ideas for themselves, and they were extended from religious manuscripts to encompass a variety of early medieval artefacts. In 1989, the British Museum, the National Museum of Ireland and the National Museums of Scotland

Medieval Revival in fin-de-siècle France (Aldershot 2003), pp. 19-21; M. Dietler, "“Our Ancestors the Gauls": Archaeology, Ethnic Nationalism, and the Manipulation of Celtic Identity in Modern Europe', American Anthropologist II.96 (1994) 584-605, at pp. 591-93.

${ }^{35}$ On the similarities of 'Celticism' to 'Germanism', see G. Halsall, Barbarian Migrations and the Roman West, 376-568 (Cambridge 2007), pp. 22-25.

${ }^{36}$ On the long historiography of this debate since the mid- $19^{\text {th }}$ century, see C. Nordenfalk, 'One Hundred and Fifty Years of Varying Views on the Early Insular Gospel Books', in M. Ryan (ed.) Ireland and Insular Art, A.D. 500-1200 (Dublin 1987) 1-6; N. Netzer, 'Style: A History of Uses and Abuses in the Study of Insular Art', in M. Redknap et al. (eds) Pattern and Purpose in Insular Art (Oxford 2001) 169-177. Other origins have also been suggested for these books, including locations in Pictland and East Anglia.

${ }^{37}$ E.A. Lowe, Codices Latini Antiquiores, vol.2 (Oxford 1935; $2^{\text {nd }}$ edn 1972), p. xii; Nordenfalk 1987 , p. 2.

${ }^{38}$ C. Nordenfalk, Celtic and Anglo-Saxon Painting (London 1977), p. 11.

${ }^{39}$ P. Sims-Williams, 'The Visionary Celt: The Construction of an Ethnic Preconception', Cambridge Medieval Celtic Studies 11 (1986) 71-96, traces the creation of the image to the $19^{\text {th }}$ century, and notes its increased popularity in scholarship of the 1970s and 80s. See also J. Sheehy, The Rediscovery of Ireland's Past: The Celtic Revival, 1830-1930 (London 1980). Oscar Wilde proposed: 'Now that the Celtic spirit has become the leaven of our politics, there is no reason why it should not contribute something to our decorative art' (Pall Mall Gazette, 17 December 1887, quoted in A. Carpenter, Art and Architecture of Ireland, vol.1 (Dublin 2014), p. 12). 
collaborated on an exhibition of early medieval Celtic metalwork with the title The Work of Angels: the phrase came from Gerald of Wales's description (c. 1188) of an illuminated gospel book seen in Kildare, Ireland, but was here applied, on the basis of style and belief in a unifying Celtic culture, to secular as well as religious objects from all non-Anglo-Saxon areas of the British Isles. ${ }^{40}$ The catalogue's prefatory notes from the UK Prime Minister Margaret Thatcher and Irish Taoiseach Charles Haughey reflect the political message of collaboration between the nations that the exhibition represented. ${ }^{41}$

In response to debates over its Irish, British or English origins, scholars have adopted the term 'Insular' to refer to the art of the early medieval British Isles, and sometimes more particularly the style distinctive to these Gospel books and associated items. ${ }^{42}$ It is recognized that one of the benefits of this term is that it avoids ethnic attribution. However, two explicit definitions of the term claimed that the art it described 'was produced by people who today refer to themselves as English, Irish, Scottish and Welsh, or, at times, following modern political boundaries, as British and Irish', or, similarly, was created in the islands 'occupied by those peoples who today call themselves English, Irish, Scots, and Welsh, or sometimes Irish and British' ${ }^{43}$ Even with the shift in terminology, the assumption that the producers of early medieval art were somehow the same 'people(s)' as the current inhabitants of the regions demonstrates that the connection of early medieval art to national identity remains strong. ${ }^{44}$

The role of early medieval art in the formation of Celtic identity was explored in the British Museum exhibition Celts: Art and Identity in 2015 (this time, the collaboration was pursued with the National Museums of Scotland only). It is interesting to note that reviewers rejected the exhibition's narrative that there was no single Celtic identity across millennia, preferring to understand the objects as the expression of a single people. The tongue-in-cheek, but enthusiastic, endorsement of the Guardian's art critic Jonathan Jones encapsulates the power of cultural stereotypes, embedded narratives of early medieval history, and the dominance of the ethnic paradigm: 'If you leave untouched by mystic fire, you have no imagination. Or are a Saxon. ${ }^{45}$ Public visitors, on the other hand, seem to have been more receptive to the

\footnotetext{
${ }^{40}$ S. Youngs, (ed.) 'The Work of Angels': Masterpieces of Celtic Metalwork, 6th-9th centuries AD (London 1989); Giraldus Cambrensis, Topographia Hibernica, in J.F. Dimock, (ed.) Giraldi Cambrensis Opera, vol.5 (London 1867), Distinctio. II, ch. 38: 'liber ille mirandus ... tam delicatas et subtiles, tam arctas et artitas, tam nodosas et vinculatim colligatas, tamque recentibus adhuc coloribus illustratas notare poteris intricaturas, ut vere haec omnia potius angelica quam humana diligentia jam asseveraveris esse composita'.

41 I. Wood, The Modern Origins of the Early Middle Ages (Oxford 2013), p. 323.

${ }^{42}$ L. Nees, 'Ethnic and Primitive Paradigms in the Study of Early Medieval Art', in C. Chazelle and F. Lifshitz (eds) Paradigms and Methods in Early Medieval Studies (Basingstoke 2007) 41-60, p. 49: the term originated in the field of palaeography, coined by Ludwig Traube ('insulare Schrift') to describe the largely indistinguishable Irish, British and Anglo-Saxon script. For a description of the style, see G. Henderson and I. Henderson, The Art of the Picts: Sculpture and Metalwork in Early Medieval Scotland (London 2004), pp. 15-29.

${ }^{43}$ Netzer 2001, p. 169; R. Cramp, 'The Insular Tradition: An Overview', in C.E. Karkov et al (eds) The Insular Tradition (Albany 1997) 283-299, at p. 283.

${ }^{44}$ Of course, the historiography of the art of the British Isles is not unique in these respects - the early medieval histories of various 'ethnic' groups have been co-opted as the original sources of modern European nations: Geary 2002, esp. pp. 15-40.

45 J. Jones, 'Jonathan Jones's Top 10 Art Shows of 2015', The Guardian (16 December 2015) http://www.theguardian.com/artanddesign/2015/dec/16/jonathan-joness-top-10-art-shows-of-2015 [accessed 16/12/15]
} 
exhibition's narrative, even though many were motivated to visit because of their own 'Celtic connections'. ${ }^{46}$

Thus, while not uncomplicated, it is still a successful strategy for museums to present to the public a narrative in which early medieval peoples represent the origins of nations. However, Ian Wood has interpreted the more recent history of early medieval exhibitions as primarily reflecting an image of the origins of Europe. Since 1989, this has grown to encompass central and eastern Europe as well. ${ }^{47}$ A 2007 exhibition in Moscow, which displayed Merovingian artefacts looted from Berlin at the end of the Second World War, was called 'Europe without Borders'. The early medieval gallery in the British Museum, redesigned and re-opened in 2014, bears the title 'Sutton Hoo and Europe', now placing the Anglo-Saxons at the centre of European origins. Such presentations may not be entirely novel: European unity had earlier provided an alternative model to Germanist displays of the early medieval past. ${ }^{48}$ Given Germany's current dominance within the European Union, these ideas no longer stand in counterpoint to each other. The British Library's 'Anglo-Saxon Kingdoms' exhibition of 201819 emphasised continental connections and was viewed by many as a statement of European identity following the $2016 \mathrm{EU}$ referendum. ${ }^{49}$ As so often in the history of collecting and display, new interpretations not only reflect continuing discoveries, but also the changed meaning of the artefacts with respect to contemporary international relations.

\section{But is it art?}

During the nineteenth-century formation of early medieval museum collections, 'barbarian' objects were usually considered as of purely historical or ethnographic interest, rather than viewed as art in their own right. In 1857 the curator of antiquities at the Louvre, Adrien de Longpérier, dismissed a call for the establishment of a Celtic Museum, because he did not consider these unimpressive objects to be on a level with the classical, Egyptian and Near Eastern art displayed in the galleries of the Louvre.$^{50}$ Meanwhile in Berlin, the ethnographic, prehistoric and early historic collections were grouped together; they had been excluded from the Altes Museum and were eventually moved from the Neues Museum to the Völkerkundemuseum (Ethnological Museum) in $1886 .{ }^{51}$ Their status reflected a long-held feeling that early medieval artefacts did not belong beside the more impressive art of the greater civilizations of classical antiquity. A similar attitude prevailed at the British Museum where, in 1866, the newly created department for British and Medieval Antiquities also encompassed Ethnography. ${ }^{52}$ Although the collection of early medieval artefacts was spurred by the desire to represent 'national antiquities' alongside the cultures of other civilizations, even their greatest supporters did not claim that they were on a par with classical Greek

\footnotetext{
${ }^{46}$ Morris Hargreaves McIntyre, Celtic Connections: A summative report of Celts: Art and Identity at the British Museum (British Museum, unpublished evaluation report, 2016), pp. 3, 7-8, 17, 30.

${ }^{47}$ Wood 2013, pp. 316-26.

${ }^{48}$ Effros 2012, p. 167.

${ }^{49}$ C. Breay and J. Story (eds), Anglo-Saxon Kingdoms: Art, Word, War (London, 2018). At the time of writing, the UK population had voted to leave the EU; how the changing political context may affect this 'European' trend in exhibition programming remains to be seen.

${ }^{50}$ Effros 2012, p. 267.

${ }^{51}$ Blauert with Bähr 2012, p. 80.

52 Wilson 2002, pp. 140-42.
} 
sculpture. In his diatribe against the rejection of the Faussett collection, Roach Smith explained,

It was rumoured that one of the Trustees, who attended at the meetings (if such they could be called) which repudiated the Saxon antiquities, urged that they were not works of high art! As well might he have complained that our Saxon or Norman ancestors were not Greeks or Romans... But viewing antiquities only as works of high art, is exhibiting a low sense of the object the historian has in view in studying them. ${ }^{53}$

Early medieval antiquities were valued by nineteenth-century collectors primarily for the information they revealed about historical movements and the primitive, direct expression of the nation's character, rather than valued as cultural achievements in themselves. The widespread association with ethnography, meanwhile, seems to have been more than a marriage of convenience (although at the British Museum it arose immediately from Franks's own interests), but an application of the idea that contemporary 'primitive' societies could profitably be compared with earlier stages in European societies' development.

Various intellectual and artistic movements, however, led to a growing appreciation of the beauty and skill of early medieval art. In particular, explorations of ornamental traditions and the decorative stimulated interest in 'primitive' art of all forms. While this viewpoint came from a new direction, it also reinforced the association between the creations of early medieval barbarians and the arts of 'exotic' societies - now, on an aesthetic as well as an anthropological level. Owen Jones's The Grammar of Ornament (1856) placed early medieval motifs - which he termed 'Celtic Ornament' - within his survey of Ornamental Art, ranging from the art of 'Savage Tribes' through ancient cultures, Arabian, Indian and Chinese designs, to designs from medieval and renaissance Europe. The 'Celtic' motifs, which in fact encompassed many Anglo-Saxon examples, were drawn almost exclusively from illuminated manuscripts (supplemented with a few examples of stone sculpture). ${ }^{54}$ The accompanying essay by J. O. Westwood justified the inclusion of these early medieval ornaments through a strong sense of national pride and British distinctiveness in an age of darkness; in doing so, Westwood chimed in with Jones's own consistent emphasis on ornamental art as a function of instinct. Yet although Jones believed that ornament should be appropriate to form and function, his collection of plates representing disembodied decorative motifs from diverse material contexts somewhat undercut his philosophy. ${ }^{55}$

Jones's work was an early contribution to a new tendency to place aesthetic value on the decorative. ${ }^{56}$ In the second half of the nineteenth century, this attitude began to influence perceptions of early medieval museum objects, as well as illuminated manuscripts, particularly under influence from the Arts and Crafts movement. In particular, the period of 'Celtic Revival' (at its height in the years 1880-1930) stimulated more general enthusiasm for

\footnotetext{
${ }^{53}$ Smith 1854, pp. 11-12.

${ }^{54}$ J.O. Westwood, 'Celtic Ornament', in O. Jones, The Grammar of Ornament (London 1856), p. 2:

'The genius of the inhabitants of the British Islands has, in all ages, been indicated by productions of a class or style singularly at variance with those of the rest of the world'. See also E.H. Gombrich, The Sense of Order: A Study in the Psychology of Decorative Art (Oxford 1979; $2^{\text {nd }}$ edn 1984), pp. 51-55. J. Collis, 'The Sheffield Origins of Celtic Art', in C. Gosden et al. (eds) Celtic Art in Europe - Making Connections: Essays in Honour of Vincent Megaw on His 80th birthday (Oxford 2014) 19-27, at pp. 22-25, discusses Westwood's definition of the term 'Celtic Art'.

${ }^{55}$ Jones 1856, p. 1: 'It is more than probable that the first result of sending forth to the world this collection will be seriously to increase this dangerous tendency...'

${ }^{56}$ On the problem of defining 'the decorative', see Gombrich 1984, pp. x, 17-19.
} 
so-called 'Celtic' motifs, now based on early medieval metalwork, stone sculpture and manuscripts. ${ }^{57}$ Yet replicas and new artworks inspired by early medieval forms removed them from their original religious contexts: in the 1890s one of Edmond Johnson's bestselling replicas was a sugar bowl based on the Ardagh Chalice. ${ }^{58}$ Some years later, one of Johnson's former employees likewise based his design for the Sam Maguire cup for the Gaelic Football Championships on the Ardagh Chalice [Fig. 1]. ${ }^{59}$ By transferring pattern and style to domestic contexts and ignoring their religious meanings and functions, such celebrations of Celtic art encouraged the notion that it was purely ornamental.

Museums' and collectors' interests in the aesthetic value of early medieval objects began to develop but, similarly, it frequently resulted in artefacts being divorced from their archaeological and historical contexts. In museums, early medieval artefacts might be arranged in typological or stylistic sequence, rather than according to burial assemblages or in relation to their original functions. ${ }^{60}$ The art market certainly accelerated the dispersal of collections and displacement of objects; North American collectors were more likely than their European counterparts to view their early medieval objects primarily in terms of aesthetics, perhaps because they were less invested in associated national histories, but also because they lacked documentation or any further information about them. ${ }^{61}$

For the Arts and Crafts movement, one aspect of historical context was particularly relevant. Its members' interest in the work of artisans rather than the elite, and of handicrafts rather than industrial production, encouraged a valorisation of these qualities in early medieval art. ${ }^{62}$ Similar anti-industrial sentiments were expressed by Baldwin Brown in his major survey of The Arts in Early England (1903-1937). He invoked William Morris to bolster his idea that the beauty of early medieval art was largely accidental, caused by the individuality of the craftsman: 'It was made for a man by a man and not by a machine for a unit of population'. ${ }^{63}$ Baldwin Brown was also clearly influenced by continental art history in his interpretations. He approvingly cited Josef Strzygowski, and elaborated on the dichotomy between classical art, which took inspiration from nature, and barbarian art, which involved the decoration of surfaces with conventionalized abstract forms. ${ }^{64}$

In writing this, Baldwin Brown responded to analytical art historical approaches which were emerging in this period. They also identified the style of early medieval art from the British Isles as primarily decorative, and pinned this classification onto the historical model of barbarians opposed to Romans. ${ }^{65}$ The dominant approach equated this dichotomy with two

\footnotetext{
${ }^{57}$ Sheehy 1980, esp. pp. 95-101, 149-55; I. Bradley, Celtic Christianity: Making Myths and Chasing Dreams (Edinburgh 1999), pp. 119-24.

${ }^{58}$ Bradley 1999, p. 139.

${ }^{59}$ F. O’Toole, 'Modern Ireland in 100 Artworks, 1928 - the Sam Maguire Cup, by Hopkins \& Hopkins', The Irish Times (7 February 2015) http://www.irishtimes.com/culture/modern-ireland-in100-artworks-1928-the-sam-maguire-cup-by-hopkins-hopkins-1.2094310 [accessed 30/03/16]. The Cup is now in the GAA Museum, Croke Park, Dublin.

${ }^{60}$ Emery and Morowitz 2003, pp. 64-88.

${ }^{61}$ Effros 2012, p. vii.

${ }^{62}$ Sheehy 1980, pp. 101, 152.

${ }^{63}$ G.B. Brown, The Arts in Early England, vol.1: The Life of Saxon England in its Relation to the Arts (1903), pp. 17-19.

${ }^{64}$ Brown 1903, pp. 38-39.

${ }^{65}$ On the distinct, but related, problems of this dichotomy in archaeology, see P. von Rummel, 'The Fading Power of Images: Romans, Barbarians, and the Uses of a Dichotomy in Early Medieval
} 
distinct artistic tendencies: the classicizing, naturalistic and figural style of Rome, and the ornamental, abstract and geometric styles of the barbarians, whether Germanic or Celtic. ${ }^{66}$ Because of the prevalence of this basic distinction, the dichotomy between barbarians and Romans is particularly difficult to reject in art history. In the mid-twentieth century this contrast enjoyed consensus, and was referred to off-hand in the first Guide to Anglo-Saxon Antiquities published by the British Museum in 1923: 'Teutonic art stands in vivid contrast to the classical'. ${ }^{67}$ The broad significance of the contrast was described most powerfully by Ernst Kitzinger, a German Jewish refugee to London, in his 1940 Early Medieval Art in the British Museum - a work which has never gone out of print. Kitzinger, who had just completed his doctoral thesis in Munich when he came to London in 1935, brought a German art-historical perspective to the British Museum for the first time, and here opened it up for an English-speaking audience. ${ }^{68}$ In this work, commissioned as an art-historical guidebook to the Museum's collection, Kitzinger claimed that 'Northern art was opposed to Mediterranean art in almost every respect' ${ }^{69}$ The barbarian style was envisaged as less sophisticated, and derived from the inherent preferences of the 'new peoples', who lacked the cultural development of Rome.

The classical-barbarian dichotomy has been undercut in recent decades, as historians and archaeologists have increasingly presented Late Antiquity as the 'Transformation of the Roman World', involving a process of reorganization and interaction between 'Romans' and 'barbarians' who were increasingly difficult to distinguish. The British Museum participated in the major European Science Foundation project of this name, leading a programme of associated exhibitions. ${ }^{70}$ Yet the dichotomy remains especially tenacious as a framework for understanding the art of the early medieval British Isles. One reason for this tenacity is that the study of Britain has only recently been subject to historical revisions similar to that of the rest of the Roman Empire, and for many the old narrative of the fall of Rome and the invasion of a barbarian people still retains its power. ${ }^{71}$ In Britain, the effects of the withdrawal of Roman forces and authority in the very early fifth century were more significant and dramatic than in any continental region, not least on the material culture of the island. Groups of migrants from the continent originated in regions outside the Empire - although they may be associated with material culture showing Roman influence. Ireland, moreover, had never been part of the Empire. A certain distinction between Roman and non-Roman - 'barbarian' cultures therefore remains prominent. ${ }^{72}$

Archaeology', in W. Pohl and G. Heydemann (eds) Post-Roman Transitions: Christian and Barbarian Identities in the Early Medieval West (Turnhout 2013), pp. 365-406.

${ }^{66}$ This contrast between Roman and barbarian may usefully be compared with the Semitic/Hellenic dichotomy discussed in Chapter 12 (pp. 299-300).

${ }^{67}$ Smith 1923, p. 10.

${ }^{68}$ J. Mitchell, 'Ernst Kitzinger, 27 December 1912 - 22 January 2003', Proceedings of the American Philosophical Society 151 (2007) 345-350.

${ }^{69}$ E. Kitzinger, Early Medieval Art in the British Museum (London 1940), p. 36; Wilson 2002, p. 237.

${ }^{70}$ L. Webster and M. Brown (eds), The Transformation of the Roman World, AD 400-900 (London 1997). See I. Wood, 'Report: The European Science Foundation's Programme on the Transformation of the Roman World and Emergence of Early Medieval Europe', Early Medieval Europe 6 (1997) 217227.

${ }^{71}$ G. Halsall, 'Movers and Shakers: The Barbarians and the Fall of Rome', Early Medieval Europe 8 (1999) 131-145 (esp. pp. 140-42, 144-45); S. Oosthuizen, The Emergence of the English (Leeds, 2019). ${ }^{72}$ For a full critical discussion of recent archaeological approaches, and a rejection of this use of material culture, see D. J. M. Harland, 'Deconstructing Anglo-Saxon Archaeology: A Critical Enquiry 
Thomas Kendrick, while Keeper of British and Medieval Antiquities at the British Museum, used this framework to explain the art of early medieval Britain. ${ }^{73}$ In his two volumes on Anglo-Saxon art (published in 1938 and 1949 respectively), Kendrick presented his central theme of 'a protracted series of conflicts between the mutually irreconcilable principles of the barbaric and the classical aesthetic systems' ${ }^{74}$ This approach enabled Kendrick, writing in an anti-Germanist atmosphere, to downplay overtly racial arguments in favour of continuity between Celtic and Germanic barbarians, attributing highly skilled techniques and more aesthetically pleasing designs to British origins. ${ }^{75}$ Kendrick's belief in the superiority of classical art emerges throughout his account of the ongoing struggles between 'the barbaric mood' which led to 'back-slidings' into the native tradition, and the 'serene and serious Romanesque discipline' of the Church. ${ }^{76}$ Kendrick's work provided the first art-historical synthesis of early medieval art from Britain, and his influences in this respect seem clear: he employed Kitzinger, who assisted him with his index of Anglo-Saxon sculpture, and commissioned him to write Early Medieval Art; Kendrick also collaborated with the newly established Courtauld Institute and the refugee Warburg Institute. ${ }^{77}$ His two volumes acted as the standard introduction and reference to Anglo-Saxon art for many years, although subsequent discoveries (not least those from Sutton Hoo) significantly changed the picture and disproved some of Kendrick's theories. ${ }^{78}$ For this reason, his overarching narrative, more than specific detail, is still influential and his categories - particularly his characterisation of barbarian and classical traditions - are still used. Leslie Webster, Kendrick's recent successor as Keeper at the British Museum, began her Anglo-Saxon Art: A New History by arguing that the two styles were not irreconcilable as he claimed, but that we should think in terms of 'assimilation, not opposition' ${ }^{79}$ Although the relationship of the two traditions may be disputed, the distinctiveness of Anglo-Saxon art continues to be attributed to its position as the boundary between the indigenous culture of the barbaric northerners and the civilization and heritage of Rome.

Although scholars now usually avoid placing these styles in an obvious hierarchy, for those trained in this way of thinking, the preference for naturalistic, figural painting and sculpture may often still exert its influence. ${ }^{80}$ Yet the identification of distinct styles with Romans and

into the Study of Ethnicity in Lowland Britain in Late Antiquity (c. 350-600)', (PhD thesis, University of York, 2017).

${ }^{73}$ Kendrick joined the department of British and Medieval Antiquities in 1922; he became Director of the Museum in 1950 until his retirement in 1958: R. Bruce-Mitford, 'Thomas Downing Kendrick, 1895-1979', in M. Lapidge (ed.) Interpreters of Early Medieval Britain (Oxford 2002) 399-424, at p. 399.

${ }^{74}$ T.D. Kendrick, Anglo-Saxon Art to AD 900 (London 1938), p. 1; id. Late Saxon and Viking Art (London 1949).

${ }^{75}$ Kendrick, Anglo-Saxon Art, pp. 64, 71-3; S. Dooley-Fairchild, 'Material Belief: A Critical History of Archaeological Approaches to Religious Change in Anglo-Saxon England' (PhD thesis, Durham University, 2012), p. 188.

${ }^{76}$ Kendrick 1938, pp. 140, 159.

${ }^{77}$ Wilson 2002, p. 246; Bruce-Mitford 2002, p. 409.

${ }^{78}$ R.N. Bailey, 'Anglo-Saxon Art: Some Forms, Orderings and Their Meanings', in S. Crawford et al. (eds) Form and Order in the Anglo-Saxon World, AD 600-1100 (Oxford 2009) 18-30, at p. 18; N. Netzer, 'Framing the Book of Durrow Inside/Outside the Anglo-Saxon World', in S. Crawford et al. (eds) Form and Order in the Anglo-Saxon World, AD 600-1100 (Oxford 2009) 65-78, at p. 68.

${ }^{79}$ L. Webster, Anglo-Saxon Art: A New History (London 2012), p. 40.

${ }^{80}$ See L. Nees, 'Recent Trends in Dating Works of Insular Art', in C. Hourihane (ed.) Insular and Anglo-Saxon Art and Thought in the Early Medieval Period (Princeton 2011) 14-30, for historiography of the dichotomy. 
barbarians is troubled not only by recent deconstructions of the latter 'ethnic' categories, but also by questioning of the basic concepts which distinguish classicizing and barbarian art. Richard Bailey has argued that what we consider 'classical' or 'barbarian' owes more to prejudices favouring particular styles of naturalistic painting than to the early medieval evidence. His brief study highlighted some examples of the varied styles and modes of representation that Anglo-Saxons would have encountered in Rome - and thus would have experienced as 'classical' - evidence which calls into question long-held beliefs about the 'barbarian' aspects of works such as the frontal, stylized, full-page miniatures of King David in the Durham Cassiodorus, an eighth-century Northumbrian manuscript. ${ }^{81}$ Likewise, the characterisation of 'barbarian' art has come under criticism. Lawrence Nees, writing as recently as 2007, called for the replacement of the 'ethnic paradigm' in early medieval art history, which he called a 'blunt scholarly tool' in its association of barbarian art with primitive, tribal culture. ${ }^{82}$ Yet, consciously or unconsciously, use of the ethnic paradigm is also ideological - not only in the association of early medieval artefacts or collections with modern nations, but also in the application of a broad barbarian-classical dichotomy. ${ }^{83}$

Feminist and post-colonial thinkers have demonstrated the assumptions underlying the relegation of ornament and the decorative to a status lower than 'art', devoid of meaning, through its codification as feminine, childish, primitive, and exotic. ${ }^{84}$ On the one hand, feminist art historians have emphasised the vitality of the ornamental, that its functionless and sensual qualities might be valued rather than despised, and that their dismissal is linked to their association with the feminine. A more radical viewpoint, however, suggests that the characterisation of ornament as irrational and meaningless serves to undermine the feminine with which it is associated; the category itself should be questioned, not merely the value attributed to it. ${ }^{85}$ From this perspective, alternative forms of artistic expression have been classed as decorative (meaningless) precisely because they are associated with (and practised by) non-hegemonic groups. The application of this idea to non-western art is apparent; ${ }^{86}$ and, by extension, to the non-Roman styles of early medieval peoples. These deconstructions have significant implications for a field which still frequently defines its interest as the interface between barbarian and classical impulses. ${ }^{87}$ If neither this dichotomy of styles, nor the dichotomy between barbarian and Roman identities can be maintained, then surely we need a different approach to early medieval art.

\section{Barbarism and religion?}

\footnotetext{
${ }^{81}$ Bailey 2009. Bailey here reiterated a point made in his England's Earliest Sculptors (Toronto 1996), pp. 16-17, since it had not been confronted by the rest of the field.

${ }^{82}$ Nees 2007, p. 50.

${ }^{83}$ This theme is echoed in several of the chapters in this volume; see especially Nadia Ali's contribution on early Islamic art as 'purely Arab' in chapter 13, pp. 385 and 390.

${ }^{84}$ See Gombrich's discussion of Adolf Loos's Ornament and Crime (1908), in which he quotes an article of 1898 by Loos: 'The Red Indian says: That woman is beautiful because she wears golden rings in her nose and in her ears. The civilized person says: this woman is beautiful because she has no rings in her nose and in her ears' (Gombrich 1984, pp. 59-61).

${ }^{85}$ L. Negrin, 'Ornament and the Feminine', Feminist Theory 7 (2006) 219-235.

${ }^{86}$ S. Kleinert, 'Deconstructing "The Decorative": The Impact of Euro-American Artistic Traditions on the Reception of Aboriginal Art and Craft', in N. Iannou (ed.) Craft in Society: An Anthology of Perspectives (South Fremantle 1992) 115-130.

${ }^{87}$ E.g. R. Deshman, The Benedictional of St AEthelwold (Princeton 1995), p. 216, and above.
} 
The underlying framework of barbarian abstraction and Roman naturalism which governs the study of early medieval - and especially Anglo-Saxon and British - art has had significant effects for the understanding of religion through visual culture.

Firstly, ethnic distinctions have dominated the field to the detriment of other possible approaches to early medieval material culture - such as a focus on religion. Although scholars have intermittently approached the topic of religion and conversion in the early Anglo-Saxon period, such approaches have never been dominant. ${ }^{88}$ Because archaeological excavations began to be pursued and artefacts collected in the nineteenth century, they were first interpreted and categorized according to contemporary intellectual preoccupations. Thus nationalist and racial concerns were embedded into the foundations of research in this field. Other aspects of research into the Anglo-Saxon period have longer disciplinary histories, which arose from other concerns. The study of Old English literature, for instance, owes much to the efforts of Archbishop of Canterbury Matthew Parker in collecting and studying the manuscripts which now form the Parker Library at Corpus Christi College, Cambridge; his interests emerged in relation to the confessional disputes of the Reformation. ${ }^{89}$ In the seventeenth century, legal and constitutional history came to dominate, again based on documentary and literary rather than material evidence. ${ }^{90}$ We may identify common threads throughout in a perception of the Anglo-Saxon age as a period of origins, but the intellectual frameworks which governed its significance differed over the centuries. The relatively recent genesis of those disciplines which trace their development from antiquarianism (particularly early medieval archaeology and art history) - as well as the continuing material discoveries in the field - mean that established categories and narratives are only now beginning to be approached critically. ${ }^{91}$ The antiquarian concentration on ethnic/national identity, and on early medieval art as a reflection of these identities as material facts, has until recently obscured other lenses through which we might wish to view early medieval material and visual culture.

Secondly, the effect of this has been to embed an implicit religious narrative based on anachronistic assumptions into the categories used to analyse early medieval art. Naturalistic art styles and particularly figural art - in the classical model - have frequently been associated with the extension of Christianity throughout the medieval world. In particular, they have been associated with the Roman Church (in western Europe; the story of Byzantine art history is of course different, as explored elsewhere in this volume). Thus the Church takes the place of the Empire in the dichotomy of Roman and barbarian. This narrative was frequently accepted because many interpreters unquestionably accepted that Christian conversion in the Early Middle Ages extended the trappings of civilization to northern Europe - not only literacy, but also art.

\footnotetext{
${ }^{88}$ Dooley-Fairchild 2012.

${ }^{89}$ For the broader cultural context, see J. Simpson, The Oxford English Literary History, vol.2. 13501547: Reform and Cultural Revolution (Oxford 2002).

${ }^{90}$ Hills 2003, pp. 31-35.

${ }^{91}$ E.g. Dooley-Fairchild 2012; J. Hawkes, 'W.G. Collingwood and Anglo-Saxon Sculpture: Art History or Archaeology?', in R. Moss (ed.) Making and Meaning in Insular Art (Dublin 2007) 259-275; N.L. Wicker, 'Art History and Archaeology: Common Ground for the New Millennium', Medieval Archaeology 43 (1999) 161-171.
} 
Such an approach is exemplified in, and was propagated by, Thomas Kendrick's Anglo-Saxon Art to AD 900 and Late Saxon and Viking Art. In the embedded narrative, classical art was introduced into Anglo-Saxon England with the first Roman missionaries under Augustine in 597. Kendrick narrated its progress in his two volumes on Anglo-Saxon art, showing how the Church, from its centre at Rome, repeatedly encouraged the Anglo-Saxons away from their instinctive barbarian aesthetic towards the classical style. He stated that there was little art to discuss before the Church began to build in England - perhaps a more convincing statement at the time, since his book was published the year before the excavation of Mound 1 at Sutton Hoo. After the conversion, however, Kendrick saw an influx of Roman art as part of the 'Golden Age' of the English Church, which subsequent scholars developed in the concept of the 'Northumbrian Renaissance'. ${ }^{92}$ Anglo-Saxon classicizing art earned the English Church, in Kendrick's eyes, the status of 'principal custodian of that immense and potent tradition'. ${ }^{93}$ It was no accident that the classical style was associated with Christianity, however. Not only was the Church's classical tradition more sophisticated, but it was also suited for religious purposes where barbarian art was not. The characterisation of barbarian art as abstract and ornamental presented it as devoid of meaning and therefore incapable of conveying mythologies and theological or doctrinal concepts. In his discussion of standing crosses, Kendrick explained that:

Their very purpose as significant monuments of Christianity demanded some measure of resistance to the in-born aesthetic tendencies of the northerner whose artistic traditions were in concept and practice totally incapable of providing a medium for such public declarations of the Faith as naturalistic figure-carving and ornament could provide. ${ }^{94}$

The final triumph of the classical tradition in England, and the accompanying rejection of the decorative style, stemmed from just these qualities. While in Kendrick's view the dominance of the superior style may have seemed inevitable, ultimately he attributed its success to its connection with the Church. ${ }^{95}$ The unfolding of Kendrick's perceived struggle between classical and barbarian aesthetics was inextricably bound up with the religious history of the British Isles.

The continuing dominance of this narrative may be seen in art historians' concentration on the Christian period in England, to the neglect of fifth- and sixth-century artefacts. In a selfproclaimed update to Kendrick's work, David Wilson, as Director of the British Museum, in 1984 published his overview of Anglo-Saxon art; he called it Anglo-Saxon Art From the Seventh Century to the Norman Conquest and explicitly set out to describe the arts of the Christian period only. The arts of the pagan Anglo-Saxons, represented exclusively by the contents of the Sutton Hoo ship burial, were treated as no more than a precursor to Christian

\footnotetext{
${ }^{92}$ C. Neuman de Vegvar, The Northumbrian Renaissance: A Study in the Transmission of Style (London and Toronto 1987); J. Hawkes and S. Mills (eds), Northumbria's Golden Age (Stroud 1999). Kendrick used this word himself, extolling 'the revolution caused by the intense and undisguised Italian taste of the leading ecclesiastics of the Roman Church in England ... that we should speak of a "renaissance" when confronted by this sudden return of humanistic art is no more than the event deserves': Kendrick 1938, p. 118.

${ }^{93}$ Kendrick 1938, p. 119.

${ }^{94}$ Kendrick 1938, p. 128. Cf. Kitzinger 1940, p. 40: 'Barbaric art was abstract to a degree that very nearly precluded its use by the Roman Church. It was inarticulate. It was not suitable as an instrument of instruction or propaganda, being incapable of conveying to the spectator a definite message. As an illustration of historical matter this style was entirely inadequate. This is undoubtedly one of the principal reasons for the much more complete submission to the Mediterranean models which Charlemagne initiated'.

${ }^{95}$ Kendrick 1949, p. 2.
} 
art. The Museum's 1991 Making of England exhibition took a similar approach in presenting the year 600 as the date of commencement. ${ }^{96}$ Although the exhibition clearly made the equation between early medieval ethnicity and modern national identity, it took as its date of commencement not the migration of the fifth century, but the year 600 - the important event was the arrival of the missionary St Augustine in 597, rather than the traditional arrival of Anglo-Saxon founder ancestors a hundred and fifty years earlier. ${ }^{97}$

Several other European exhibitions have recently followed a similar line. The Dutch exhibition of 1995, 'Willibrord and the beginning of the Netherlands' (Willibrord en het begin van Nederland), focused on the missionary to Frisia, while the 2008 Venetian exhibition on 'Rome and the Barbarians' described Christianity as 'Europe's new mortar'. 98 In such presentations, it appears that national origins lie not only in the emergence of early medieval peoples, but also in the moment of conversion to Christianity. Moreover, when conversion is presented as the cohesive moment of origin, Christianity becomes enshrined as essential to European culture.

For the British Isles, however, this narrative was complicated by the presence of different Christian traditions in the Early Middle Ages. While the Roman Church in England has been associated with classical style and figural images, allegedly opposed decorative impulses have been equated with the Irish Church, the art of which is shown to depend upon both Germanic and Celtic 'barbarian' traditions. ${ }^{99}$ However the stark distinction between two churches emerged from a long historiographical development that owed nothing to the art of the period. The division, which derives primarily from an overemphasis on the two Churches' confrontation at the Synod of Whitby, has been used as historical support in ProtestantCatholic disputes since the Reformation. ${ }^{100}$ Sixteenth-century reformers, in particular Archbishop Parker, looked to the Anglo-Saxon Church and its vernacular translations for precedents and to argue for Anglican independence. However, the early British and Irish Churches also offered the opportunity to make claims to past independence from Rome in more confrontational manner. These Churches - increasingly defined as one 'Celtic' Church - proved particularly useful to Protestant reformers in Wales, Scotland and Ireland in the sixteenth and seventeenth centuries, who recast Protestantism as a revival of the native Church, thus countering Catholic presentations of a foreign imposition. ${ }^{101}$ Notably, Archbishop Ussher of Armagh in 1631 published An answer to a challenge made by a Jesuite in Ireland. Wherein, the judgment of antiquity in the points questioned is truly delivered, and the novelty of the now Romish doctrine plainly discovered. To which is added A discourse of the religion anciently professed by the Irish and British, in which he argued that the ancient religion of the Irish, Scottish and Welsh was one and the same. ${ }^{102}$ The concept of a common Celtic Church gained in favour throughout the nineteenth century, as it chimed with the

\footnotetext{
96 Webster and Backhouse 1991.

${ }^{97}$ Webster and Backhouse 1991.

${ }^{98}$ N. James, '(Rome + Barbarians) = Europe?', Antiquity 82 (2008) 493-496, p. 494.

99 J. Hines, 'Religion: The Limits of Knowledge', in id. (ed.) The Anglo-Saxons from the Migration Period to the Eighth Century: An Ethnographic Perspective (Woodbridge 1997) 375-401, at p. 391.

${ }^{100}$ See A. Arceo, 'Rethinking the Synod of Whitby and Northumbrian Monastic Sites', Haskins Society Journal 20 (2008) 19-30.

${ }^{101}$ Bradley 1999, pp. 93-103.

102 Ussher, J. An answer to a challenge made by a Jesuite in Ireland. Wherein, the judgment of antiquity in the points questioned is truly delivered, and the novelty of the now Romish doctrine plainly discovered. To which is added A discourse of the religion anciently professed by the Irish and British (London 1631).
} 
Romantic notion of the 'Visionary Celt'. ${ }^{103}$ To the features of independence and monasticism already identified as characteristic of the Celtic Church were added an emphasis on spirituality and an appreciation of nature. ${ }^{104}$ While recognition of the Celtic Church grew during the twentieth century, interest was always as much popular as scholarly. ${ }^{105}$ Historians of the period now dispute whether the term 'Celtic Church' is of any use at all; ${ }^{106}$ Wendy Davies actually referred to it as 'harmful', in a piece which revealed her exasperation at its continuing invocation despite lack of supporting evidence. ${ }^{107}$ The central criticism is that it implies similarity and uniformity where there was none, and moreover there was no centrally administered structure or identity.

Importantly, art had little part to play in the formulation of this concept. Excluding manuscripts, Anglo-Saxon and Celtic art were rarely identified as such before the later nineteenth century. Even then, with the definition of a distinct 'Celtic' style, art played a peripheral role in perceptions of the early medieval Church. ${ }^{108}$ Only in the twentieth century were ideas of a specific Celtic art - developed in a racial, culture history framework and envisaged as purely decorative - matched to notions of a spiritual, nature-oriented Celtic Church, in conflict with Rome. The equation of non-figural art with this Celtic Church then reinforces Protestant, iconophobic views of a spiritual and pure early British (or Irish) Christianity. The idea of non-representational art as characteristic of Celtic Christianity holds significant weight in modern historiography, and it has recently been proposed that this characteristic was a result of a distinct Celtic theology. ${ }^{109}$ While this may be the case, it is difficult to assess the argument independently of historic uses of the Celtic Church in Catholic-Protestant disputes. Furthermore, a religious explanation linked to the austerity of the 'Celtic Church' does not appear to be sufficient in explaining the dominance of decorative designs in early medieval Britain, since the art of the pre-Christian Anglo-Saxons reveals a similar interest in ornament rather than figural representation. Nor, for that matter, does an

\footnotetext{
103 Sims-Williams 1986.

${ }^{104}$ Emerging as the background to art history in Brown 1903, p. 149: 'side by side with the normal Christianity of the Romanized West, a Christianity of Celtic origin and of a more emotional type, with a correspondingly loose Church organization in which the bishop had a more restricted office and a totally different social position'.

105 A connected thread, also with a strong popular component, is the interest in Celtic paganism: e.g. M. Green, Celtic Goddesses: Warriors, Virgins and Mothers (London 1995).

106 J. Blair, The Church in Anglo-Saxon Society (Oxford 2005), p. 5; K. Hughes, 'The Celtic Church: Is This a Valid Concept?', Cambridge Medieval Celtic Studies 1 (1981) 1-20; repr. in ead. Church and Society in Ireland, AD 400-1200, ed. D.N. Dumville (London 1987) no. xviii.

${ }^{107}$ W. Davies, 'The Myth of the Celtic Church', in N. Edwards and A. Lane (eds) The Early Church in Wales and the West (Oxford 1992) 12-21, at p. 12.

${ }^{108}$ On the developing definition of 'Celtic Art', in which Kemble and Franks played an early but crucial role, see Collis 2014. On the independent development of the concept of a 'Celtic Church', see Davies 1992, p. 13.

${ }^{109}$ M.W. Herren and S.A. Brown, Christ in Celtic Christianity: Britain and Ireland from the Fifth to the Tenth Century (Woodbridge 2002; paperback edn 2012) have argued that the decorative and symbolic art of the early Celtic Church resulted from its 'Pelagian' theology, which - they suggested involved strictures against images (p. 18). Their definition of this 'common Celtic Church' (of the midfifth to early seventh centuries) describes it as a 'low Church', in which the sacraments played a less significant role than elsewhere, with an ambivalence about the Eucharist in particular, and in which liturgy, buildings and artefacts were 'modest' and lacked 'pomp and ceremony': S.A. Brown and M.W. Herren, 'Neo-Pelagianism, Early Insular Religious Art, and the Image of Christ', in M. Redknap et al. (eds) Pattern and Purpose in Insular Art (Oxford 2001) 61-71, at p. 61. On the Eucharist, Herren and Brown 2012, pp. 126-27.
} 
ethnic explanation, since both Celtic and Anglo-Saxon styles preserve this quality (and actually frequently appear in combination).

This brings us to the third point: commencing discussion around the year 600 and focusing on Christian art relegates objects of the pagan period to a lower status. This periodization reflects a feeling that the metalwork found in fifth- and sixth-century graves does not constitute art but is rather, for instance, 'secular crafts' produced by 'decorative artisans'. ${ }^{110}$ While materials recovered from burials may be relatively plentiful, their embellishment is not (usually) figural, they are (primarily) functional objects, and their techniques belong to the socalled 'minor arts'. Because of these 'barbarian' characteristics, art historians have approached these objects almost exclusively in terms of technique and style. A considerable proportion of all scholarship on pagan-period metalwork, for example, focuses on the classification, development and chronological relationship of styles of animal ornament (often following Bernhard Salin's 1904 terminology of Style I and Style II; Kendrick preferred the terms 'Helmet Style' and 'Ribbon Style'), rather than exploring the meanings of these decorative approaches in varied contexts and applications. ${ }^{111}$ It is only once the classicizing influence of Rome is felt that studies of iconography and aesthetics proliferate. Thus the Roman Church mission of 597 appears, judging from modern art historical research, to have brought both art and religion to England.

Pagan religion has never become a prominent field of investigation for art historians. For instance, in the twenty-five years since the International Conferences on Insular Art began, studies of Christian iconography have multiplied, but it is hard to locate references to nonChristian belief in the pages of its proceedings. In contrast, cautious but varied archaeological approaches to paganism have investigated non-Christian Anglo-Saxon beliefs through the analysis of objects, monuments and sites dating from the fifth to eighth centuries. David Wilson's Anglo-Saxon Paganism, which relies solely on archaeological information and its relation to religious practice, remains a solid point of reference; but in his book on AngloSaxon Art, Wilson made only cursory reference to paganism and suggested that art did not provide useful information in this respect. ${ }^{112}$ Once the idea that furnished burials were necessarily pagan was demolished, the topic of non-Christian belief became less popular, but in recent decades new approaches to this evidence have proved fruitful. Martin Carver recently lamented the dominance of the Church subsequent to conversion - 'the dark curtain of Christianity' - because it put an end to 'original thought about the supernatural' for the next millennium. ${ }^{113}$ Among archaeologists such as Carver, this attitude is perhaps understandable: from the period of Christianization onwards, their typical materials (furnished burials in particular) become scarcer and less suggestive in terms of religious belief. In contrast, materials which appeal to art historical approaches to religion - displaying figural iconography and links to liturgical and scriptural texts - are much richer from the Christian period. Indeed, there has been a 'quiet revolution' in the study of Anglo-Saxon and

\footnotetext{
${ }^{110}$ Neuman de Vegvar 1987, pp. 60, 68.

${ }^{111}$ E.g. Webster 2012, pp. 49-67; B. Salin, Die altgermanische Thierornamentik (Stockholm 1904); Kendrick 1938, pp. 74-85. Cf. J. Hawkes, 'Symbolic Lives: The Visual Evidence', in J. Hines (ed.) The Anglo-Saxons from the Migration Period to the Eighth Century: An Ethnographic Perspective (Woodbridge 1997) 311-338, at pp. 317-18.

${ }_{112}$ D.M. Wilson, Anglo-Saxon Paganism (London 1992); D.M. Wilson, Anglo-Saxon Art: From the Seventh Century to the Norman Conquest (London 1984), pp. 13, 27.

${ }^{113}$ M. Carver, 'Agency, Intellect and the Archaeological Agenda', in id. et al. (eds) Signals of Belief in Early England: Anglo-Saxon Paganism Revisited (Oxford 2010) 1-20, at p. 16; see this collection as a whole for the 'cutting edge' of this field of research.
} 
Insular Christian art in recent years, as art historians interpret these works as 'visual exegesis'. ${ }^{114}$ Studies of individual artworks, such as those by Carol Neuman de Vegvar, Éamonn Ó Carragáin and Jennifer O'Reilly, reveal the sophisticated messages that Christian images contained, and the particular qualities that enabled them to convey religious meaning and elicit spiritual experience. These iconographic approaches rely on the use of religious and contemporary literature; for this reason, similar attempts have not been made for nonChristian works of art.

However, a few examples demonstrate that artworks from the pre-Christian or conversion period can enlighten us about beliefs current at that time in Britain. George Speake led the way in his work on Anglo-Saxon Animal Art (1980), which combined archaeological and arthistorical approaches. ${ }^{115}$ The archaeologist Tania Dickinson has revealed the possibilities in understanding certain motifs, particularly zoomorphic images, in symbolic ways. ${ }^{116}$ The birds of prey and pike-like fishes presented on the front of shields may now be seen as predatory beasts of battle, with mythological links to Woden; their apotropaic status as symbols of protection enhanced the shield's function [Fig. 2]. Birds decorating drinking horns and buckles, however, might relate more to the aristocratic pastimes of the Germanic warrior, and thus symbols of status. ${ }^{117}$ Art historians have demonstrated how we can move beyond linking iconographic representation to supposedly stable symbolic meanings. Jane Hawkes contributed a chapter entitled 'Symbolic Lives' to the European Science Foundation volume on the Anglo-Saxons. Under this title, Hawkes was able to avoid the rigidity of the usual dichotomy between Christian and pagan and, through a focus on animal imagery and interlace, reveal the role of art in early Anglo-Saxon belief, practice and protection. She proposed, for instance, the prominence of interlacing designs as images to be disentangled by the viewer, but noted the transition from pagan-period zoomorphs [Fig. 3] to a Christian form with hidden crosses. ${ }^{118}$ Such attempts remain rare, however, and meet resistance. In the same volume, John Hines argued that in the absence of text we cannot know about religion. ${ }^{119}$ The reluctance to consider early objects as 'religious' in any sense suggests that many art historians are also unwilling to entertain the converse, that art may be able to tell scholars about the religion of the period, especially where texts are lacking. Certainly, we cannot make the same kind of analyses as have been completed so successfully for Christian works of art. But, after all, it is not the same kind of art that we are dealing with - and, given the many differences, probably not the same kind of religion.

These issues are of relevance not merely to the early Anglo-Saxon period, but to any expressions of pagan or unorthodox belief. Viking Age stone sculpture is another body of material for which the association of barbaric art with abstraction, and Christian art with naturalism, has on occasion acted to prevent religious readings. Kendrick's detailed

\footnotetext{
${ }^{114}$ C. Neuman de Vegvar, 'Remembering Jerusalem: Architecture and Meaning in Insular Canon Table Arcades', in R. Moss (ed.) Making and Meaning in Insular Art (Dublin 2007) 242-256, at p. 242.

115 G. Speake, Anglo-Saxon Animal Art and Its Germanic Background (Oxford 1980).

116 T. Dickinson, 'Symbols of Protection: The Significance of Animal-Ornamented Shields in Early Anglo-Saxon England', Medieval Archaeology 49 (2005) 109-163.

117 Dickinson 2005, p. 161; Hawkes 1997, pp. 320-22.

118 Hawkes 1997, pp. 328-33.

${ }^{119}$ Hines 1997 , pp. 377, 381. Of course, this is an issue faced by scholars of many periods and religions, especially for prehistoric art: see P. Taylor (ed.), Iconography Without Texts (London 2008).
} 
discussion of the ninth- and tenth-century sculpture from northern England provides a pertinent example.

Kendrick's interpretation of Viking Age stone sculpture, which built on the work of W. G. Collingwood, was moulded by his key theme of the conflict between barbarian and classical art, but it was also dominated by his understanding of religious and national history. Because many of the monuments of the late ninth and tenth centuries did not display the same styles as Scandinavian art, and there was no prior tradition of stone relief carving in Scandinavia, Kendrick attributed the stone sculpture throughout this period to Anglo-Saxon artists. The distribution of such sculptures in areas dominated by Scandinavian settlers he gave a social explanation - they were, in fact, monuments created by brave ecclesiastics and representative of 'a victory of Christendom' over the pagan settlers. ${ }^{120}$ Once again, the inclination was to associate works of art - even when considered to be of very low standard - with Christianity and the Church. Subsequent work has in fact suggested the contrary; qualitative and quantitative differences in sculpture from the ninth century onwards may be explained by a shift from monastic production and display to the influence of lay patronage. ${ }^{121}$ Moreover, Kendrick's pride in the English church led him to minimise the importance of foreign influence, despite seeing the sculpture of this period as purely barbaric in style. The 'reversion' to barbarian style resulted from a combination of the state of chaos and poverty that resulted from the viking conquests which, in stripping away all civilized discipline, allowed Anglo-Saxon sculptors to revert to their 'deep-seated and almost ineradicable aesthetic instinct' for the Hiberno-Saxon (i.e. Insular) style, and a concession to the taste of Scandinavian settlers. ${ }^{122}$ The minimal foreign impact was not directly stylistic, but made itself felt in its barbarian quality: 'wild', 'rugged', 'unruly', 'unrestful', 'violent', 'tempestuous' but at the same time 'heavy', 'clumsy' and 'even'. ${ }^{123}$ With his stress on continuity, and a degree of English pride, Kendrick proclaimed that at least the Anglo-Saxon craftsmen managed to work within their own tradition and not succumb to the even more barbaric Scandinavian styles. ${ }^{124}$

Kendrick's designation of such northern sculpture as 'violently barbaric', but ultimately Anglo-Saxon and Christian, determined his interpretation of the monuments' decoration and iconography. ${ }^{125}$ Although the most popular motifs constitute decorative interlace and vinescrolls, a number of stones bear figural imagery with Christian, pagan and secular themes, frequently in combination. The most prominent example is the Gosforth Cross, which stands in a churchyard in Cumbria, and displays a Crucifixion scene alongside monsters and warriors, which are usually interpreted as episodes from Ragnarök, the final battle and destruction of the gods in Norse mythology [Figs 4 and 5]. It is difficult to square such artworks - which clearly challenge Kendrick's belief that barbarian art was necessarily decorative and not figural - with his assertion that they were monuments of Christianity raised in defiance of paganism. Indeed, Kendrick used his historical narrative of the resilient northern Church to deny the monuments any pagan significance. Suggestions that the pagan

\footnotetext{
${ }^{120}$ Kendrick 1949, p. 56.

${ }^{121}$ R.N. Bailey, Viking Age Sculpture in Northern England (London 1980), pp. 82-84.

${ }^{122}$ Kendrick 1949, p. 57.

${ }^{123}$ Kendrick 1949, pp. 88, 93, 96-97.

${ }^{124}$ Kendrick 1949, pp. 96-97: 'Let us count it to their credit that the imported designs were swept quickly into the background, and that the Viking taste was allowed to do little more than occasionally introduce a note of unrestful dishevelment that by disturbing the smoother and more orderly English designs, has left us an easily recognizable period-style most appropriate to a turbulent age'.

${ }^{125}$ Kendrick 1949, p. 78.
} 
myths were used as parallels for Christian doctrine had been popular since the mid-nineteenth century, ${ }^{126}$ but Kendrick refused them credence, because

this seems to me to suggest a weakness that the Church Militant of this heroic age would have repudiated; for the appeasement of the heathen was a policy that the pugnacious ecclesiastics of the Dark Ages never considered. The crosses are witnesses to indomitable Christian courage and are themselves proof to the contrary. ${ }^{127}$

Thus, Kendrick rejected the interpretations of his antiquarian predecessors George Stephens, W.S. Calverley, and W.G. Collingwood, who were fascinated by the mythological images on sculpture such as the Gosforth Cross and their possible Christian meanings. ${ }^{128}$ Instead, Kendrick denied that the iconography was an issue at all. He simply asserted that what appeared figural was, on these barbarian monuments, merely pattern and contained no iconographic meaning, since

the figure-subject itself had degenerated into a purely ornamental composition without serious doctrinal significance. It was not so much a scene or an episode in a story as an intriguing pattern... Figure-subjects, in other words, had ceased to be significant... For by this time both the angels and Sigurd were, like a run of interlace, just decoration. ${ }^{129}$

Kendrick developed this argument for the various regions of the north, noting that, when figures were featured, they dissolved into pattern. He dismissed as purely ornamental the iconography of monuments such as the Gosforth Cross and the Kirkby Stephen 'bound Devil' - a fragmentary cross shaft, also from Cumbria, bearing an image of a horned male figure with bound arms, legs, and stomach, which has alternatively been identified as the Norse god Loki. ${ }^{130}$ In making this argument, Kendrick re-iterated the abstract, and inferior, nature of barbarian art, and also avoided any discussion of the role of art in negotiating pagan and Christian religions.

Numerous illuminating studies of northern sculpture in this period have now been produced, many of which demonstrate the invalidity of Kendrick's astonishing assertion that the stone carvings of the Viking Age north were 'just decoration'. Although many of them build on Kendrick's work, particularly the card catalogue of stone sculpture which he compiled, they have departed considerably from his interpretation. ${ }^{131}$ The Gosforth cross's combination of crucifixion scene with figures and monsters relating to Ragnarök, for example, has received a significant amount of iconographic analysis. ${ }^{132}$ Most of these interpretations stress the predominantly Christian context of the sculptures' creation, and suggest Christian readings of the pagan mythological scenes represented. These analyses imply that Christians within England translated pagan mythologies into figural representation in stone. However, several scenes from pagan mythology have only been convincingly identified in the English context through comparison with art from Scandinavia, notably the Gotland picture stones. Although these are a very unusual and perhaps unique development in Scandinavia, it is suggested that

${ }^{126}$ Bailey 1980, p. 101.

${ }^{127}$ Kendrick 1949, p. 59.

${ }^{128}$ Townend 2009, pp. 120-53.

${ }^{129}$ Kendrick 1949, pp. 59-60.

${ }^{130}$ L. Kopár, Gods and Settlers: The Iconography of Norse Mythology in Anglo-Scandinavian Sculpture (Turnhout 2012), p. 85.

${ }^{131}$ J. Lang, Corpus of Anglo-Saxon Stone Sculpture, Vol. III: York and East Yorkshire, (Oxford 1991), p. 1.

${ }^{132}$ E.g. R. Bailey, 'Scandinavian Myth on Viking-Period Stone Sculpture in England', in G. Barnes and M.C. Ross (eds) Old Norse Myths: Literature and Society (Sydney 2000) 15-23; Karkov 2011, pp. 255 58; Kopár 2012, pp. xvii-xxi, 90-104. 
they reflect wider iconographic traditions on textiles - a suggestion supported by the rare preserved tapestries bearing images of people, animals and carts from the ninth-century Oseberg ship burial in Norway. ${ }^{133}$ Therefore, these diachronic comparisons raise questions about the role of art in the respective religious traditions, and, at the very least, encourage us to separate figural, narrative images from purely Roman (Christian) contexts.

It remains difficult for art historians to integrate Viking Age stone sculpture into overarching views of Anglo-Saxon art. The art of northern England defies ethnic and religious categories; and northern artists seemed to be appealing to a very different standard from those of the south. Wilson disparaged the material as 'so crude as to be of little interest to the style historian'; in his view, interest lay precisely in the iconography and the information this gave about the interaction of paganism and Christianity. ${ }^{134}$ However, this was a matter for the social historian, since it made little impact on the development of art in England. He contrasted 'the scruffy sculpture of the north' unfavourably with 'the glitter, sensitivity and competence of the art of the south', which was the real subject of art history. It was the art of the south which, for Wilson, earned the label 'the golden age of English art' ${ }^{135}$ Indeed, the British Museum exhibition of that title, which opened the same year that Wilson's book was published, simply ignored the northern traditions of the period it covered - presumably because they were considered separate and inferior to the Winchester style and southern art, and possibly because they were by now seen as (Anglo-)Scandinavian rather than AngloSaxon. ${ }^{136}$ Research into northern stone sculpture has advanced as something of a field of its own, benefiting from new discoveries (such as fifty pieces in York Minster) and the publication of ten volumes of the British Academy's Corpus of Anglo-Saxon Stone Sculpture. ${ }^{137}$ In readings sensitive to political, ethnic and social contexts, recent work stresses the regional variation and local significance of Viking Age stone monuments. ${ }^{138}$ As a result, although it has moved our understandings of style, iconography and culture far beyond the Romantic reconstructions of the nineteenth century and the dismissive attitudes of the midtwentieth, northern Viking Age sculpture has not found a place within general histories of Anglo-Saxon art. Overviews find it difficult to integrate the art of the north with that of the south in the later Anglo-Saxon period because at this point artists across England do not seem to have been following one artistic trajectory. Neither can northern stone sculpture be considered a purely 'viking' art, since much of it was demonstrably created by native artists and within local traditions. Viking Age art thus challenges the ethnic paradigm, since it proves impossible to fit into a teleological narrative of English national history.

\footnotetext{
${ }^{133}$ Bailey 1980, pp.105, 137, 142. Other traditions of figural images in what appear to have been religious contexts have been identified in Scandinavia, such as the gold foils with embracing figures from the island of Bornholm: N.L. Wicker, 'The Scandinavian Animal Styles in Response to Mediterranean and Christian Narrative Art', in M. Carver (ed.) The Cross Goes North: Processes of Conversion in Northern Europe, AD 300-1300 (York 2003) 531-550, at p. 539.

${ }^{134}$ Wilson $1984 \mathrm{a}$, p. 150.

${ }^{135}$ Wilson 1984a, pp. 152-54.

136 J. Backhouse et al. (eds), The Golden Age of Anglo-Saxon Art, 966-1066 (London 1984).

${ }^{137}$ R. Cramp (ed.) Corpus of Anglo-Saxon Stone Sculpture (Oxford 1984-); B. Hope-Taylor, Under York Minster: Archaeological Discoveries, 1966-1971 (York 1971).

${ }^{138}$ For instance, D. Stocker, 'Monuments and Merchants: Irregularities in the Distribution of Stone Sculpture in Lincolnshire and Yorkshire in the Tenth Century', 179-212, and P. Sidebottom, 'Viking Age Stone Monuments and Social Identity in Derbyshire', 213-236, both in D.M. Hadley and J.D. Richards (eds) Cultures in Contact: Scandinavian Settlement in England in the Ninth and Tenth Centuries (Turnhout 2000).
} 
Artefacts and images such as these, which cannot be placed comfortably within dichotomies of pagan/barbarian/decorative, or Christian/Roman/naturalistic, nor be assigned clear ethnic designations, thus lead us to search for new ways of viewing early medieval art. When in contact, of course, these dualistic categories may well have had contemporary meaning in relation to each other. In Kendrick's presentation, Alfred and his successors completely rejected the barbarian style because they perceived it to be intimately connected to the viking enemy. In this situation, 'the issue was raised to a different plane, classicism then standing for the stability of inherited culture, and barbaric art for the evil forces that then threatened English society with disruption'. ${ }^{139}$ Likewise, Nancy Wicker has proposed that decorative and zoomorphic styles dominated Scandinavian art of the Viking Age precisely because they created a distinction from Christian art - Kendrick's argument from the opposite perspective. ${ }^{140}$ Karkov hints at the power of a cultural explanation of difference when she discusses 'the creation of a set of cultural binaries that has carried over into modern scholarship: Christian/pagan, literate/illiterate, civilized/barbaric, peaceful/violent. By extension, Viking art was read as pagan, illiterate, barbaric and violent in subject matter and in its technique'. ${ }^{141}$ But it is imperative that we separate the identification of these meanings in our subject material from values in our scholarship. Only then, when we are free from (or at least aware of) an imposed narrative of ethnic and religious history, can early medieval art speak to us about the religious life of its users and creators.

New discoveries also lead to the rejection of existing categories and the creation of new perspectives. For the British Museum, the most significant excavation and acquisition for the early medieval collection was the ship burial from Mound One at Sutton Hoo, excavated in 1939 and donated to the Museum [Figs 2 and 3]. Because of the precise moment when they were discovered, some attempts were made to link the Sutton Hoo finds to English national identity, emphasising British and Swedish connections rather than Germanic. ${ }^{142}$ But the multitude of artefacts and influences in the burial assemblage - identified as Germanic, Scandinavian, Celtic, Merovingian and Byzantine - did not encourage ethno-nationalist interpretations. The artefacts and their relationships are so rich and complex that to reduce the Sutton Hoo finds to an assessment of ethnicity would have been impossibly limiting. The use of both 'Roman' and 'barbarian' visual languages, and pagan and Christian symbols, in relation to a single individual, cast those binaries in a new light. The effects of the discovery on Anglo-Saxon scholarship were perhaps slow to materialise, but ultimately deeply significant. Rupert Bruce-Mitford finally published his detailed report, after the re-excavation of the mound, between 1975 and $1983 .{ }^{143}$ Subsequent research raised a plethora of new questions related to the early Anglo-Saxon period and its material culture: the Sutton Hoo ship burial prompted scholars to think about connections, rather than distinctions, within the early medieval British Isles; the development of kingship, elite culture and new communities; the emergent Anglo-Saxon kingdoms' to the past; relationships with powers near and far; monumentality and the landscape; and, of course, creative beliefs and practices which

\footnotetext{
${ }^{139}$ Kendrick 1938, p. 221.

140 Wicker 2003.

${ }^{141}$ Karkov 2011, p. 249.

${ }^{142}$ W. Filmer-Sankey, 'Was Redwald a European? Sutton Hoo as a Reflection of British Attitudes to Europe', in M. Henig and T. J. Smith (eds), Collectanea Antiqua: Essays in Memory of Sonia Chadwick Hawkes (Oxford 2007), pp. 61-6.

${ }^{143}$ R. Bruce-Mitford, The Sutton Hoo Ship Burial, 3 vols (London 1975-83); Wilson 2002, p. 289.
} 
reflected a changing and conflicted religious context. ${ }^{144}$ Moreover, investigation of Sutton Hoo and these themes required that art historical and archaeological approaches combined once again. Kendrick never rewrote Anglo-Saxon Art to A.D. 900 to take account of the Sutton Hoo discoveries, which had fundamentally changed the evidence base only a year after publication. But it would not have been a simple matter for him to do so, since his broad approach to characterising early medieval art as a clash of barbarian and classical impulses would not have adequately explained the finds. Instead, as new material continues to do whether spectacular and dramatic, such as the 2009 discovery of the Staffordshire Hoard, or the exponential increase of small finds evidence recorded by the Portable Antiquities Scheme - they required new ways of thinking about the art of the Early Middle Ages.

${ }^{144}$ Key publications include M. Carver, Sutton Hoo: A Seventh-Century Princely Burial Ground and Its Context (London 2005); id. Sutton Hoo: Burial Ground of Kings? (London 1998); C.B. Kendall and P.S. Wells (eds) Voyage to the Other World: The Legacy of Sutton Hoo (Minneapolis 1992); R.T. Farrell and C. Neuman de Vegvar (eds) Sutton Hoo: Fifty Years After (Oxford OH 1992); A.C. Evans, The Sutton Hoo Ship Burial (London 1986). 